\title{
Pneumatosis intestinalis presenting as a partial small bowel obstruction
}

\author{
William Dominic Marley, Benjamin Dodd, Gary Spence
}

Department of General Surgery, Ulster Hospital, Belfast, UK

\section{Correspondence to} William Dominic Marley, wmarley01@qub.ac.uk
To cite: Marley WD, Dodd B, Spence G. BMJ Case Reports Published online: 17 December 2012 doi:10.1136/bcr-2012007291

\section{DESCRIPTION}

An 88-year-old man presented to casualty with severe abdominal pain and vomiting. Chest $\mathrm{x}$-ray was suspicious for free intraperitoneal air. Abdominal x-ray was in keeping with small bowel obstruction. CT also suggested free intraperitoneal gas and the patient proceeded to laparotomy (figure 1).

Intraoperatively, a moderate volume of free fluid was noted; however, there was no free intraperitoneal air. Gross pneumatosis and diverticulosis of the small bowel was present (figure 2). A volvulus secondary to adhesions was divided and reduced. All small bowel remained viable. Postoperative recovery was unremarkable and the patient has since been discharged from follow-up.

Pneumatosis is a rare condition characterised by gas in the submucosa and subserosa of the bowel wall. The condition was initially described in 1783 by Du Vernoi and has carried multiple pseudonyms since then. It is felt that the incidence may be increasing secondary to the use of CT for intraabdominal pathology. ${ }^{1}$

Pneumatosis has a wide range of pathogenesis including pulmonary disease, scleroderma, immunosuppression and multiple gastrointestinal pathologies. It is also believed the incidence may be increasing secondary to iatrogenic causes, including instrumentation of the gastrointestinal tract and prescribed medications. ${ }^{2}$

Pear $e t a l^{3}$ identified bowel ischaemia, infarction, neutropaenic colitis, volvulus and sepsis as the most

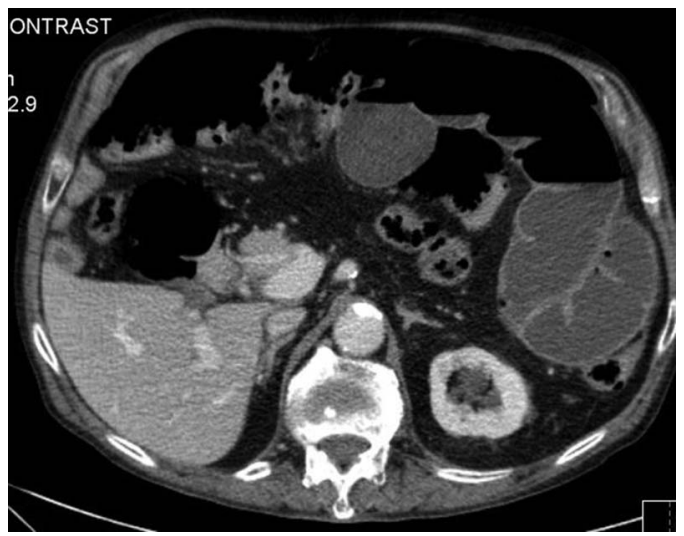

Figure 1 Transverse plane CT scan of the abdomen showing bubbles of air within the bowel wall.

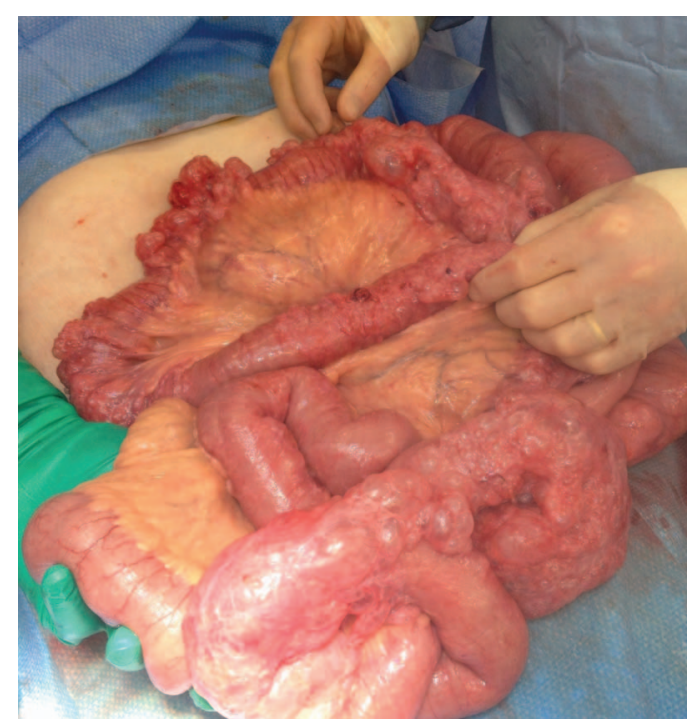

Figure 2 Gross pneumatosis of the small bowel identified at the time of laparotomy.

common life-threatening causes of intramural gas. Surgical intervention may be required in patients presenting with evidence of obstruction, ischaemic bowel and an acute abdomen.

\section{Learning points}

- Pneumatosis intestinalis is usually a sign of an underlying pathology.

- It may be managed conservatively or surgically —careful clinical assessment is required to guide treatment.

Competing interests None.

Patient consent Obtained.

Provenance and peer review Not commissioned; externally peer reviewed.

\section{REFERENCES}

1 Heng Y, Schuffler MD, Haggitt RC. Pneumatosis intestinalis: a review. Am J Gastroenterol 1995;90:1747-58.

2 Ho LM, Paulson EK, Thompson WM. Pneumatosis intestinalis in the adult: benign to life-threatening causes. AJR Am J Roentgenol 2007; 188:1604-13.

3 Pear BL. Pneumatosis intestinalis: a review. Radiology 1998:207:13-19. 
Copyright 2012 BMJ Publishing Group. All rights reserved. For permission to reuse any of this content visit http://group.bmj.com/group/rights-licensing/permissions.

BMJ Case Report Fellows may re-use this article for personal use and teaching without any further permission.

Become a Fellow of BMJ Case Reports today and you can:

- Submit as many cases as you like

- Enjoy fast sympathetic peer review and rapid publication of accepted articles

- Access all the published articles

- Re-use any of the published material for personal use and teaching without further permission

For information on Institutional Fellowships contact consortiasales@bmjgroup.com

Visit casereports.bmj.com for more articles like this and to become a Fellow 